The BDJ News section accepts items that include general news, latest research and diary events that interest our readers. Press releases or articles may be edited, and should include a colour photograph if possible. Please direct your correspondence to the News Editor, Arveen Bajaj at the BDJ,

64 Wimpole Street WIG 8YS or by e-mail to bdj@bda.org

\section{University honours}

Chief Dental Officer for England, Professor Raman Bedi has been awarded a Doctor of Science from the University of Bristol.

He was among 14 honorary degree recipients to receive the award from the University earlier this month. Professor Bedi studied dentistry at Bristol graduating in 1976, and completed his training in Sheffield before returning to Bristol for a theological degree at Trinity College.

He then undertook academic appointments at the Universities of Manchester and Hong Kong. He became director for the Centre for Transcultural Oral Health at the Eastman Dental Institute in 1986.

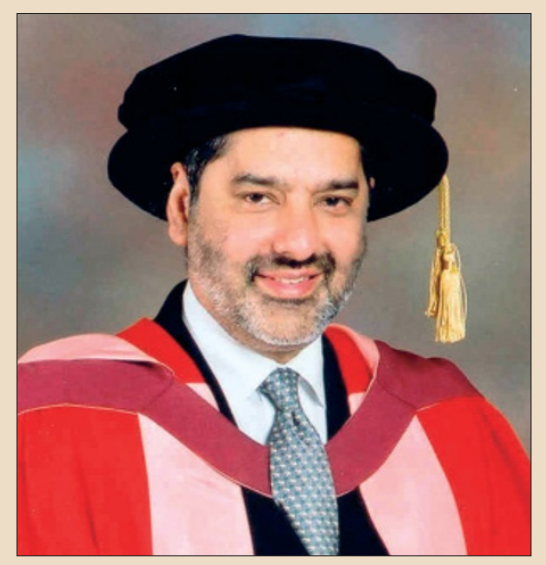

\section{High tooth decay}

The British Dental Association has published a league table of children's dental health by parliamentary constituency, showing how many have unacceptable high levels of tooth decay.

According to the survey, the difference in the dental health of five-year-old children from fluoridated and non-fluoridated areas is marked.

In Manchester, the average five-yearold has three times as many decayed, missing or filled teeth as the average five-year-old in Birmingham, where water supplies have been fluoridated for over 40 years.

\title{
RNDS day held
}

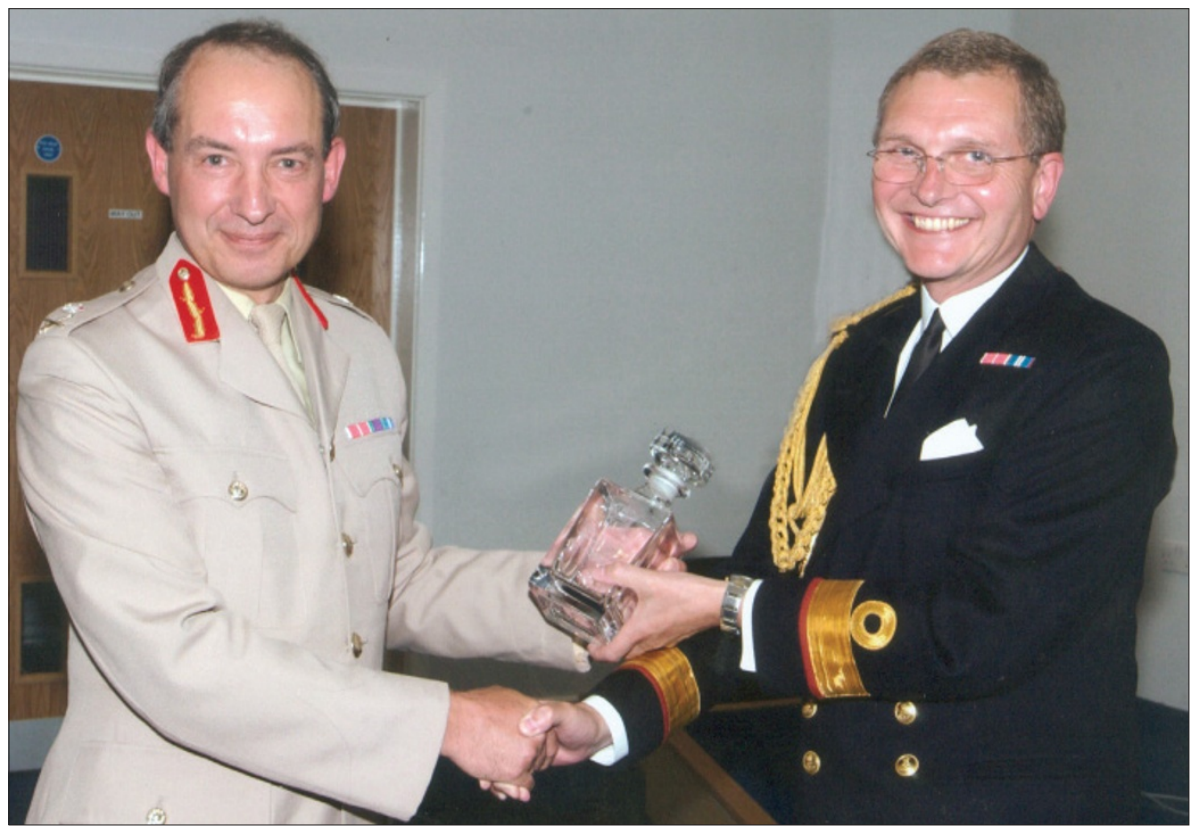

Surgeon Commodore (D) Geoff Myers, Director of Naval Dental Services presents a decanter to Lieutenant General K. O'Donoghue, Deputy Chief of the Defence Staff (Health) at the triennial Royal Naval Dental Services Wood Lecture Day. General O'Donoghue spoke on the Defence Health Programme at the lecture day which was held at Fort Blockhouse.

\section{Child protection initiative launched}

The NSPCC have launched a new initiative aimed at creating awareness of child protection. The EduCare Child Protection Awareness in Health programme is the first of its kind to address the need for all those who work in healthcare to play a part in protecting children.

The NSPCC claims that everyone in healthcare, including dentists, have a role to play in recognising and reporting suspected child abuse and in supporting families under

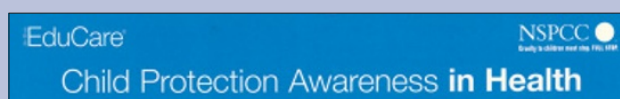

Child Protection Awareness in Health

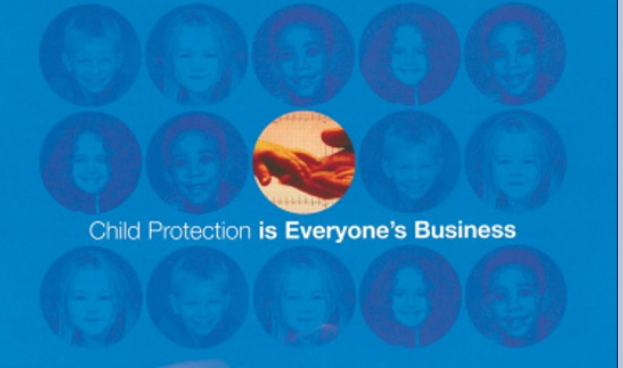

stress. It adds that better awareness will contribute to better communication on child abuse concerns between staff which can be crucial in piecing together the full picture of what may be happening to a child.

The distance learning programme covers issues such as good practice principles, the role in protecting children, how to recognise signs of abuse and what to do if you are concerned about a child.

It can be completed at work or at home at the participant's own pace so it can fit in with demanding work schedules. For further information please contact EduCare on 01926436219 . 


\section{DIARY}

October 2003

BDA CDS Group Annual Presidential and

Scientific Conference 2003

Date: 17-18.10.03

Venue: Marriott Worsley Park Hotel,

Manchester

Contact: Marianne Fraser

Tel: 02075634199

E-mail: m.fraser@bda.org

9th Biennial Congress of the International Academy of Periodontology

Date: 24-27.10.03

Venue: Cape Town

Tel: +27 219389245

Fax: +27219332649

E-mail:sunevr@sun.ac.za

International Conference on Evidencebased Advanced Dentistry

Date: 31.10.03-03.11.03

Venue: Hong Kong

Tel: +44 (852) 28718787

Fax: +44 (852) 28718898

E-mail: confdept@hkam.org.hk

May 2004

BDA National Annual Conference

Date: 06.05.04 - 08-05.04

Contact: Events Office,

British Dental Association

Venue: Bournemouth International

Centre

Tel: +44 (0) 2075634590

Fax: +44 (0) 2075634591

E-mail: events@bda.org

\section{New committee members elected at GDC}

The council has elected the following new committees. The membership of each committee includes at least one PCD member, one lay member, one dentist member and one CDO. All the elected members of the committees have been elected by and from the full council membership.

\section{Education Committee \\ David Barnard - Dentist \\ Mabel Slater - PCD \\ David Herbert - Lay \\ Raman Bedi - CDO \\ Paul Cook \\ Denis Toppin \\ Michael Martin}

Registration Committee

Meredyth Bell - Dentist

Sheila Phillips - PCD

Lesley Kant - Lay

Doreen Wilson - CDO

Alison Lockyer

Joe Rich

Andrew Keetley

Standards Committee

John Chope - Dentist

Rosemarie Khan - PCD

Sally Irvine - Lay
Paul Langmaid - CDO

Peter Catchpole

Brian Coulter

Anthony Kilcoyne

Fitness to Practice Policy Committee

David Phillips - Dentist

Julia Brewin - PCD

Joan Aitkin - Lay

Doreen Wilson - CD0

Trevor Griffiths

Carol Varlaam

Finance and Human Resources

Committee

Richard Graham - Dentist

Sheila Phillips - PCD

Caroline Abel-Smith - Lay

Ray Watkins - CDO

Suzanne Cosgrave

Derek Prentice

Raj Raja Rayan

\section{Professional Conduct Committee update}

The Professional Conduct Committee met for ten days between 7-18 July and heard four cases. Judgement was postponed on the case of Robert Julian Hossack's and the case of David Russel Girdham was adjourned.

Sundeep Luthra was found guilty of serious professional misconduct as was Neville Young Choon Kan who was admonished.
The Health Committee met for two days on 30 June and 1 July and heard seven cases consisting of three initial and four resumed cases.

of the initial cases, three dentists were found to be seriously impaired. Of the resumed cases, three dentists had their suspensions renewed for 12 months and one dentist was suspended for six months having broken his conditions. 


\section{Solihull practice achieves IIP}

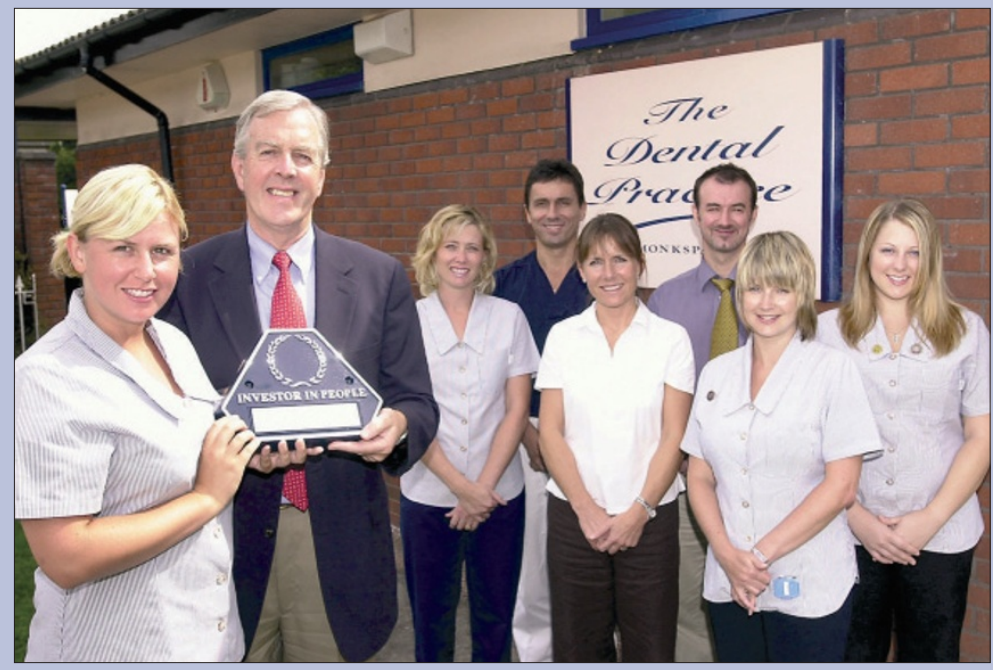

The Dental Practice in Monkspath, Solihull has been recognised as an Investor in People. Opened in 1988, the practice has developed to comprise three dentists including two specialists, and three hygienists. Practice administrator Jo Fuller (left) receives the award from Malcolm Clark of Solihull Business Link.

\section{New endodontic appointment}

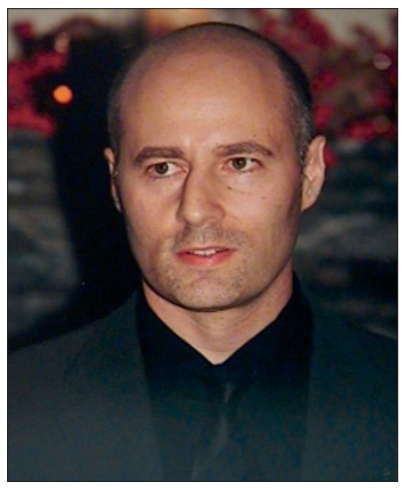

Richard Kahan has been appointed programme coordinator and clinical lead for CPD Programmes in Endodontics by Eastman CPD.

His objective will be to further expand and improve the endodontic courses run by the institute and will be working on the development of a full range of short and longer certificated endodontic programmes.

Dr Kahan has been a long time Eastman endodontic teacher, lecturing for many years on the Eastman's MSc courses and supervising graduate specialist clinics.

He was closely involved in establishing the Endodontic Skills Laboratory at 123 Gray's Inn Road.

\section{African endeavour}

Forgotten Africa, a charity that works with some of the poorest communities in East Africa is preparing a project in which a retired dentist will travel to Uganda next year for a month to help extend acute treatment provision and provide oral hygiene education lessons to villagers.

The visit will be made to the district of Nakasongola, an intensely rural area of central Uganda either in January/Febru-

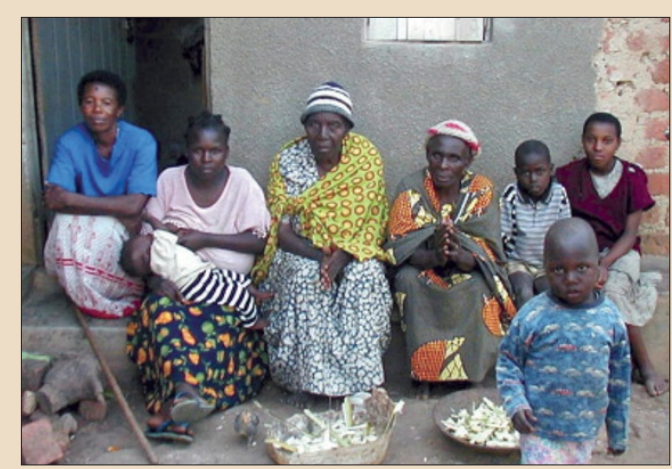
ary or July/August. There is no hospital and no fully qualified dentist in the district, instead it has just two dental assistants who travel between the eight village dispensaries and Nakasongola town offering extractions. Oral hygiene education is also extremely limited.

The charity is looking for another dentist to accompany retired dentist and trustee of Forgotten Africa Peter Le Coyte on the trip, and is also looking for manufacturers and dentists to donate needles, local anaesthetics and hundreds of toothbrushes. For further information contact 01367250111. 